\title{
Entheseal inflammation in SpA and new treatment modalities
}

\author{
SpA'da enteziyal enflamasyon ve yeni tedavi yöntemleri
}

\author{
(1) Pamir Atagündüz \\ Marmara University Faculty of Medicine, Department of Rheumatology, Istanbul, Turkey
}

\begin{abstract}
The importance of enthesitis in the pathogenesis of spondyloarthritis (SpA) has been known since the 80s. The main reason for the differentiation of the clinical features of SpA from other inflammatory rheumatic diseases such as rheumatoid arthritis (RA) is the presence of enthesitis, and radiological studies show that the inflammation in SpA starts with enthesitis and there is a transition to synovitis. Recently, due to the recurrent microtraumas caused by mechanical factors in the enthesis region, enthesitis, and thereby new bone formation in individuals with an appropriate genetic background such as ankylosing spondylitis (AS), psoriatic arthritis (PsA), and enteropathic arthritis (EA) has been reported. Diagnosis of enthesitis is important in the differential diagnosis of inflammatory rheumatic diseases as well as in its treatment. The development of new therapeutic agents such as anti-IL-17, IL-12/23, and JAKi that are effective in enthesis requires an update of the SpA therapy.
\end{abstract}

Keywords: Spondyloarthritis, enthesitis, therapy, IL-17, IL-12/23, JAKi

\section{Öz}

Entezit varlığının spondiloartrit (SpA) patogenizindeki önemi 80 'li yıllardan beri bilinmektedir. SpA'nın klinik özelliklerinin, romatoid artrit (RA) gibi diğer enflamatuvar romatizmal hastalıklardan ayrımasının temel nedeni entezit varlığıdır ve radyolojik çalıșmalar SpA'da enflamasyonun özellikle entezit ile bașladığını ve buradan sinovite doğru bir geçiș olduğunu göstermektedir. Son dönemde mekanik faktörlerin, entezis bölgesinde olușturduğu tekrarlamayı mikrotravmalar nedeni ile, entezite ve buradan da uygun genetik yapıya sahip bireylerde ankilozan spondilit (AS), psöriatik artrit (PsA) ve enteropatik artrit (EA) hastalarında görülen yeni kemik olușumuna neden olduğu birden çok çalıșma ile bildirilmiștir. Entezit tanısı, enflamatuvar romatizmal hastalığın ayırıı tanısında olduğu kadar tedavisinde de önem tașımaktadır. Entezite etkili Anti IL-17, IL-12/23, JAKi gibi yeni tedavi ajanlarının gelișimi SpA tedavisinin güncellenmesini gerektirmektedir.

Anahtar Kelimeler: Spondiloartrit, entezit, tedavi, IL-17, IL-12/23, JAKi

\section{Introduction}

Since the beginning of the eighties, enthesitis was considered to be the key element in the pathogenesis of spondyloarthritis (SpA). Clinically, the distinct pattern of involved joints from that of rheumatoid arthritis, and several imaging studies of early disease suggest that enthesitis is the first site of inflammation in patients with SpA. The importance of enthesitis in the pathogenesis of SpA has increased in recent years with the recognition of the importance of mechanical factors in genetically susceptible patients, which may be responsible in both the enthesitis and the new bone formation. ${ }^{[1]}$ In a large study population the prevalence of enthesitis in PsA (psoriatic arthritis) was reported to be $35 \% .^{[2]}$ With the use of imaging modalities detected enthesitis has a much higher prevalence, approaching about $70 \%$ in patients with PsA. ${ }^{[3]}$

In the daily routine, enthesitis is diagnosed clinically by assessing tenderness at the entheseal site. One should be careful in making the diagnosis because other clinical signs of inflammation such as swelling are absent and an over diagnosis is possible in individuals with disturbed pain perception. Based on clinical judgment, The Spondyloarthritis Research Consortium of Canada (SPARCC) index (16 sites of enthesis), the Leeds enthesitis index (LEI) (6 sites of enthesis) and the Maastricht Ankylosing Spondylitis Enthesitis score (MASES) (addresses the axial entheseal sites) are the commonly used enthesitis indices today.

Correspondence / İletișim:

Pamir Atagündüz, Marmara University Faculty of Medicine, Department of Rheumatology, İstanbul, Turkey

ORCID ID: orcid.org/0000-0002-6393-7461

${ }^{\circ}$ Copyright 2020 by the Turkish Society for Rheumatology / Journal of Turkish Society for Rheumatology published by Galenos Publishing House.

๑Telif Hakkı 2020 Türkiye Romatoloji Derneği / Ulusal Romatoloji Dergisi, Galenos Yayınevi tarafından yayınlanmıștır. 


\section{Inflammation - Pathogenesis}

The term enthesis derives from the ancient Greek word for insertion. In fact, enthesis describes the insertion of tendons and ligaments into the bone surface. ${ }^{[4]}$ Entheses transmit mechanical forces from muscles to bones. Anatomy of the entheses is important for understanding the process of inflammation. Entheses are mostly located outside the joints and enthesitis usually occurs outside the joint. Unlike in rheumatoid arthritis (RA), in diseases such as PsA or axial SpA (axSpA) synovitis appears later in the presence of enthesitis.

Entheses are complex and distinguished anatomical structures and may be regarded as "entheseal complexes" or "enthesis organs". ${ }^{[5,6]}$ A transition zone - the fibrocartilage - is critical in transduction of mechanical forces between the tendon and bone. Overuse may result in inflammation of the enthesis organ on sole sites such as "tennis elbow" and usually resolves upon eliminating the precipitating factor, ie. overuse or overload, without a tendency towards chronicity. Currently, it is not clear, whether the pathogenesis of enthesitis occurring in conjunction with axSpA in genetically predisposed individuals differs from the enthesitis of mechanical overloading. But enthesitis seen in these diseases tend to occur at sites mechanical overload and anatomical resemblance of the insertion points of nail and flexor tendons to the skeleton provides some support for the role of enthesis/enthesitis in SpA-related skin and joint manifestations. ${ }^{[7]}$

Since classical components of autoimmunity, such as B cell activation, follicular reactions and autoantibody formation, it is currently assumed that inflammation of the entheses are driven mostly by an innate immune response. Resolution of clinical symptoms right after the treatment with non-steroidal anti-inflammatory agents (NSAIIDs) in SpA associated enthesitis suggests a possible pivotal role of prostaglandin E2 (PGE2) in the early disease stages. Critically, IL-17 production by T cells and activation of the IL-23-IL-17 pathway occurs under the influence of local PGE2 ${ }^{[8]}$ Additionally, the role of over-expressed IL-23 triggering enthesitis in the absence of micro trauma has been already shown by animal studies. ${ }^{[9]}$ A recent finding implies that the site of enthesis incorporates cells that are IL-23responsive and these cells are responsible in producing the IL-17 and TNF, classically the target cytokines of treatment in $\operatorname{axSpA} .{ }^{[10,11]}$

The production of IL-17 seems to be a crucial in neutrophil migration and activation and possibly links IL-23IL-17 activation with the effector phase of inflammation. ${ }^{[12]}$

\section{Concepts of Treatment}

Our current knowledge on the treatment of enthesitis is limited because of the lack of clinical studies addressing specifically enthesitis as the primary outcome of under treatment. Cytokine targeting biologic agents become multifaceted and provide a solid ground for efficacious treatment and serve as clinical evidence for the role of certain pro-inflammatory cytokines in the pathogenesis of enthesitis. ${ }^{[13]}$ Despite both the high prevalence of clinical enthesitis in axSpA patients and the additional cases detected in patients when newer imaging techniques are used, studies dealing with enthesitis and the long used drugs of NSAIDs, sulfasalazine (SSZ) and methotrexate (MTX) in the treatment of the whole SpA group do not provide a solid data on efficacy.

DMARDs are use in symptomatic treatment of axSpA as first line drugs. But there is some evidence for their effects on radiographic progression, as well. First randomized clinical trial reporting a positive effect on radiographic progression incorporated some design issues, unfortunately. In this study patients were randomly allocated to receive either continuous treatment with NSAIDs or on-demand treatment with NSAIDs for a period of 2 years. ${ }^{[14]}$ After two years, patients under continuous celecoxib treatment were reported to have a lesser degree of radiographic progression. Later on these finding were criticized on the basis of both almost equivalent dosages of celecoxib used by both study groups and "how such a small difference in dosage could translate into measurable radiographic effects...". ${ }^{[15]}$ In another confirmatory study with diclofenac in a similar design, continuous treatment with diclofenac over 2 years did not reduce radiographic progression compared with on-demand treatment in AS. ${ }^{[16]}$ Clearly, new studies are necessary.

Widely used conventional disease modifying drugs (cDMARDS) such as SSZ, MTX and leflunamide (LEF) does not have efficacy in treating entheseal inflammation.

Apremilast, the phosphodiesterase 4 inhibitor, has been shown to be effective on enthesitis with a clear resolution in half of the patients after 1 year of treatment. Unfortunately, MASES scoring used in this study to assess the affect of apremilast focuses mainly on axial enthesitis and the effect on peripheral enthesitis still remains to be addressed. ${ }^{[17]}$

Anti-TNFa agents are widely used in the treatment of axSpA and their beneficial effect on enthesitis is shown in several studies; for infliximab in heel enthesitis, for adalimumab; and etanercept, golimumab and certolizumab for the peripheral enthesitis. ${ }^{[18-22]}$

IL-23-IL-17A axis plays a crucial role in the pathogenesis of both axSpA and psoriasis. The monoclonal antibody 
ustekinumab is effective in controlling inflammation seen in axSpA with its ability of blocking the p40 subunit of IL-12 and IL-23. Recently, it has been shown that ustekinumab is effective in treating peripheral enthesitis in active PsA patients. ${ }^{[23]}$

Although IL-17A cytokine expression has been detected in a multitude of autoimmune and auto-inflammatory diseases, a key role in psoriasis, PsA and axSpA is evident. [24] Enthesitis seen in this disease group is triggered predominantly by an innate immune response. In humans, IL-17A likely acts as an amplifier of enthesitis, inducing several other cytokines by resident mesenchymal cells. ${ }^{[25,26]}$

The efficacy of secukinumab, a fully human monoclonal antibody against IL-17A, in controlling key clinical manifestations of axSpA such as both peripheral and axial arthritis, enthesitis and psoriasis, has been published with well-designed studies. ${ }^{[27,28]}$

The efficacy of IL-17A inhibitors on several clinical manifestations of AS and PsA is supported by the data efficacy of Ixekizumab, a humanised anti-IL-17A antibody, in both TNF-naive and resistant cases, as well. ${ }^{[29,30]}$

Treatment with the IL-17 inhibitors secukinumab and ixekizumab results in improvements in enthesitis scores with resolution of enthesitis in $~ 50 \%$ of the patients treated with secukinumab and $30-40 \%$ of those treated with ixekizumab. $[28,31]$

\section{Conclusion}

Enthesitis is a common complication of axSpA. The use of imaging techniques implies that it has even a higher prevalence with its subclinical forms. Animal studies suggest that enthesitis, driven by both mechanical and genetic factors, may be the underlying mechanism of new bone formation. New and multifaceted line of biologic agents makes it more important than ever that patients with predominantly distinct manifestations of axSpA be treated accordingly.

\section{References}

1. Jacques P, Lambrecht S, Verheugen E, et al. Proof of concept: enthesitis and new bone formation in spondyloarthritis are driven by mechanical strain and stromal cells. Ann Rheum Dis 2014;73:437-45.

2. Polachek A, Li S, Chandran V, Gladman DD. Clinical enthesitis in a prospective longitudinal psoriatic arthritis cohort: Incidence, prevalence, characteristics and outcome. Arthritis Care Res (Hoboken) 2016;69:1685-91.

3. Pinto-TasendoJA, Diaz de Rabago EG, Fernández Sueiro JL, et al. Prevalence of enthesitis and concordance of enthesitis exploration with ultrasound versus clinical exploration in psoriatic arthritis. Ann Rheum Dis 2010;69:580.
4. Ball J. Enthesopathy of rheumatoid and ankylosing spondylitis. Ann Rheum Dis 1971;30:213-23.

5. Thomopoulos S, Genin GM, Galatz LM. The development and morphogenesis of the tendon- to-bone insertion - what development can teach us about healing. J Musculoskelet Neuronal Interact 2010;10:35-45.

6. Watad A, Cuthbert RJ, Amital H, McGonagle D. Enthesitis: Much More Than Focal Insertion Point Inflammation. Curr Rheumatol Rep 2018;20:41.

7. Benjamin M, Kaiser E, Milz S. Structure-function relationships in tendons: a review. J Anat 2008;212:211-28.

8. Paulissen SM, van Hamburg JP, Davelaar N, Asmawidjaja PS, Hazes JMW, Lubberts E. Synovial fibroblasts directly induce Th17 pathogenicity via the cyclooxygenase/prostaglandin E2 pathway, independent of IL-23. J Immunol 2013;191:1364-72.

9. Sherlock JP, Joyce-Shaikh B, Turner SP, et al. IL-23 induces spondyloarthropathy by acting on ROR- $\gamma \mathrm{t}+\mathrm{CD} 3+\mathrm{CD} 4-\mathrm{CD} 8-$ entheseal resident T cells. Nat Med 2012;18:1069-76.

10. Lories RJ, McInnes I. Primed for inflammation: enthesis resident cells. Nat Med 2012;18:1018-9.

11. Hamada S, Umemura M, Shiono T, et al. IL-17A produced by $\gamma \delta \mathrm{T}$ cells plays a critical role in innate immunity against listeria monocytogenes infection in the liver. J Immunol 2008;181:3456-63.

12. Karbach S, Croxford AL, Oelze M, et al. Interleukin 17 drives vascular inflammation, endothelial dysfunction, and arterial hypertension in psoriasis-like skin disease. Arterioscler Thromb Vasc Biol 2014;34:2658-68.

13. Schett G, Elewaut D, McInnes IB, Dayer JM, Neurath MF. How cytokine networks fuel inflammation: toward a cytokine-based disease taxonomy. Nat Med 2013;19:822-4.

14. Wanders A, van der Heijde D, Landewé R, et al. Nonsteroidal anti inflammatory drugs reduce radiographic progression in patients with ankylosing spondylitis: a randomized clinical trial. Arthritis Rheum 2005;52:1756-65.

15. Ward MM. Prospects for disease modification in ankylosing spondylitis: do nonsteroidal antiinflammatory drugs do more than treat symptoms? Arthritis Rheum 2005;52:1634-6.

16. Sieper J, Listing J, Poddubnyy D, et al. Effect of continuous versus on-demand treatment of ankylosing spondylitis with diclofenac over 2 years on radiographic progression of the spine: results from a randomised multicentre trial (ENRADAS). Ann Rheum Dis 2016;75:1438-43. [Epub 2015 Aug 4]

17. Kavanaugh A, Mease PJ, Gomez-Reino JJ, et al. Longterm (52week) results of a phase III randomized, controlled trial of apremilast in patients with psoriatic arthritis. J Rheumatol 2015;42:479-88.

18. Antoni C, Krueger G, de Vlam K, et al. Infliximab improves signs and symptoms of psoriatic arthritis: results of the IMPACT 2 trial. Ann Rheum Dis 2005;64:1150-7.

19. Mease P, Sieper J, Bosch F, Rahman P, Karunaratne PM, Pangan AL. Randomized controlled trial of adalimumab in patients with nonpsoriatic peripheral spondyloarthritis. Arthritis Rheumatol $2015 ; 67: 914-23$.

20. Kavanaugh A, McInnes I, Mease P, et al. Golimumab, a new human tumor necrosis factor $\alpha$ antibody, administered every four weeks as a subcutaneous injection in psoriatic arthritis: twenty-four-week efficacy and safety results of a randomized, placebo-controlled study. Arthritis Rheum 2009;60:976-86. 
21. Mease P, Fleischmann R, Deodhar AA, et al. Effect of certolizumab pegol on signs and symptoms in patients with psoriatic arthritis: 24-week results of a Phase 3 double-blind randomised placebocontrolled study (RAPID-PsA). Ann Rheum Dis 2014;73:48-55.

22. Sterry W, Ortonne JP, Kirkham B, et al. Comparison of two etanercept regimens for treatment of psoriasis and psoriatic arthritis: PRESTA randomised double blind multicentre trial. BMJ 2010;340:c147.

23. McInnes IB, Kavanaugh A, Gottlieb AB, et al. Efficacy and safety of ustekinumab in patients with active psoriatic arthritis: 1 year results of the phase 3, multicentre, double-blind, placebo-controlled PSUMMIT 1 trial. Lancet 2013;382:780-9.

24. McGonagle DG, McInnes IB, Kirkham BW, Sherlock J, Moots R. The role of IL-17A in axial spondyloarthritis and psoriatic arthritis: recent advances andcontroversies. Ann Rheum Dis 2019;78:116778. [Epub 2019 Jul 5]

25. Sherlock JP, Joyce-Shaikh B, Turner SP, et al. IL-23 induces spondyloarthropathy by acting on ROR- $\gamma \mathrm{t}+\mathrm{CD} 3+\mathrm{CD} 4-\mathrm{CD} 8-$ entheseal resident T cells. Nat Med 2012;18:1069-76.

26. Kampylafka E, d'Oliveira I, Linz C, et al. Resolution of synovitis and arrest of catabolic and anabolic bone changes in patients with psoriatic arthritis by IL-17A blockade with secukinumab: results from the prospective PSARTROS study. Arthritis Res Ther 2018;20:153.

27. Braun J, Baraliakos X, Deodhar A, et al. Effect of secukinumab on clinical and radiographic outcomes in ankylosing spondylitis: 2-year results from the randomised phase III MEASURE 1 study. Ann Rheum Dis 2017;76:1070-7. [Epub 2016 Dec 13]

28. McInnes IB, Mease PJ, Kirkham B, et al. Secukinumab, a human anti-interleukin-17A monoclonal antibody, in patients with psoriatic arthritis (future 2): a randomised, double-blind, placebocontrolled, phase 3 trial. Lancet 2015;386:1137-46.

29. van der Heijde D, Cheng-Chung Wei J, Dougados M, et al. Ixekizumab, an interleukin-17A antagonist in the treatment of ankylosing spondylitis or radiographic axial spondyloarthritis in patients previously untreated with biological disease-modifying anti-rheumatic drugs (COAST-V): 16 week results of a phase 3 randomised, double-blind, active-controlled and placebocontrolled trial. Lancet 2018;392:2441-51.

30. Deodhar A, Poddubnyy D, Pacheco-Tena C, et al. Efficacy and Safety of Ixekizumab in the Treatment of Radiographic Axial Spondyloarthritis: Sixteen-Week Results from a Phase III Randomized, Double-Blind, Placebo-Controlled Trial in Patients With Prior Inadequate Response to or Intolerance of Tumor Necrosis Factor Inhibitors. Arthritis Rheumatol 2019;71:599-611.

31. Mease PJ, van der Heijde D, Ritchlin CT, et al. Ixekizumab, an interleukin-17A specific monoclonal antibody, for the treatment of biologic-naive patients with active psoriatic arthritis: results from the 24-week randomised, double-blind, placebo-controlled and active (adalimumab)-controlled period of the phase III trial SPIRIT-P1. Ann Rheum Dis 2017;76:79-87. 